\title{
Explaining age and gender differences in employment rates: a labor supply-side perspective
}

\author{
Stephan Humpert • Christian Pfeifer
}

Accepted: 3 August 2012 / Published online: 29 August 2012

(C) Institut für Arbeitsmarkt- und Berufsforschung 2012

\begin{abstract}
This paper takes a labor supply perspective (neoclassical labor supply, job search) to explain the lower employment rates of older workers and women. The basic rationale is that workers choose non-employment if their reservation wages are larger than the offered wages. Whereas the latter depend on workers' productivity and firms' decisions, reservation wages are largely determined by workers' endowments and preferences for leisure. To shed some empirical light on this issue, we use German survey data to analyze age and gender differences in reservation and entry wages, preferred and actual working hours, and satisfaction with leisure and work.
\end{abstract}

\section{Eine Erklärung alters- und geschlechtsspezifischer Unterschiede in den Beschäftigungsquoten: Die Sicht des Arbeitsangebots}

Zusammenfassung Aus Sicht des Arbeitsangebots (neoklassisches Arbeitsangebotsmodell, Suchmodelle) wird versucht die geringen Beschäftigungsquoten älterer und weiblicher Personen zu erklären. Eine Grundannahme ist dabei, dass Personen nicht beschäftigt sein werden, sofern sich ein Lohnangebot unterhalb ihres Reservationslohns befindet. Während ersteres durch produktivitätsrelevante Eigenschaften und Entscheidungen von Firmen bestimmt wird,

\footnotetext{
S. Humpert $(\bowtie) \cdot C$. Pfeifer

Institute of Economics, Leuphana University Lüneburg,

Scharnhorststr. 1, 21335 Lüneburg, Germany

e-mail: humpert@leuphana.de

C. Pfeifer

e-mail: pfeifer@leuphana.de

C. Pfeifer

IZA, Bonn, Germany
}

werden Reservationslöhne stark von individuellen Ausstattungen und Präferenzen für Freizeit bestimmt. Für die empirische Analyse benutzen wir deutsche Daten, um altersund geschlechtsspezifische Unterschiede in Reservationsund Eintrittslöhnen zu untersuchen. Des Weiteren analysieren wir gewünschte und tatsächliche Arbeitsstunden und die Zufriedenheit mit Arbeit und Freizeit.

Keywords Age · Family gap · Gender · Job search · Labor supply $\cdot$ Reservation wages

JEL Classification J14 · J22 · J64

\section{Introduction}

Empirical observation of most labor markets reveals the lower (re-)employment probability of female and older workers. In Germany, employment rates decline with age after the maximum is reached at prime ages between 30 and 50 years for men and 40 to 50 years for women (see Table 1). It can also be seen that women in all age categories have lower employment rates than men. This employment gap increases with age among younger individuals until the age of 30 to 35 years, declines among middle-aged individuals, and increases again for older individuals after the age of 50. Thus, the disadvantage from which women suffer may emerge during motherhood but is still an evident problem for older women. Non-employment often leads to individual hardship (e.g. lower consumption standards) and is also associated with burdens on society because taxpayers have to finance unemployment benefits or early retirement schemes. In times of demographic change, it is a challenge for policy and human resource management to activate the resources of female and older people in the labor market to maintain 
Table 1 Age and employment rates (in \%) for Germany

\begin{tabular}{|c|c|c|c|c|c|c|}
\hline \multirow[t]{2}{*}{ Age groups } & \multicolumn{3}{|l|}{2007} & \multicolumn{3}{|l|}{2008} \\
\hline & Men & Women & $\mathrm{M}-\mathrm{W}$ & Men & Women & $M-W$ \\
\hline $15-20$ & 34.9 & 29.6 & 5.3 & 35.5 & 29.2 & 6.3 \\
\hline $20-25$ & 74.6 & 67.6 & 7 & 74.7 & 68.5 & 6.2 \\
\hline $25-30$ & 86.7 & 75.9 & 10.8 & 86.7 & 76.2 & 10.5 \\
\hline $30-35$ & 94.9 & 77.4 & 17.5 & 94.6 & 76.4 & 18.2 \\
\hline $35-40$ & 96.4 & 80.4 & 16 & 96.0 & 80.1 & 15.9 \\
\hline $40-45$ & 95.6 & 83.7 & 11.9 & 95.6 & 83.6 & 12 \\
\hline $45-50$ & 94.4 & 83.9 & 10.5 & 94.2 & 83.9 & 10.3 \\
\hline $50-55$ & 91.4 & 79.2 & 12.2 & 90.9 & 79.7 & 11.2 \\
\hline $55-60$ & 82.7 & 66.7 & 16 & 83.3 & 67.5 & 15.8 \\
\hline $60-65$ & 45.1 & 27.4 & 17.7 & 46.6 & 29.4 & 17.2 \\
\hline$>65$ & 5.3 & 2.4 & 2.9 & 5.7 & 2.5 & 3.2 \\
\hline Total: $15-65$ & 81.6 & 69.2 & 12.4 & 81.8 & 69.6 & 12.2 \\
\hline
\end{tabular}

Source: Federal Statistical Office (Destatis), Mikrozensus 2007 and 2008

a sufficiently large labor supply. Furthermore, demographic change has brought financial problems for public retirement schemes, so that many countries have recently increased the mandatory retirement age (e.g. 65 to 67 years in Germany). It is, however, questionable whether older workers still have the necessary employment skills. Most of the political discussion focuses on labor demand-side factors, i.e. if the productivity of older workers still matches the wages paid, and assumes that old workers still want to work. This assumption might not always be correct. For example, the active participation of workers in early retirement schemes is wellknown. In this paper, we explore age and gender differences in labor supply. More specifically, we analyze reservation and entry wages, preferred and actual working hours, and satisfaction with leisure and jobs.

One stream of the literature on economics and industrial relations analyzes the labor demand side to explain age and gender-specific employment gaps (e.g. discrimination, productivity and wages). Another stream looks at the labor supply side. The neoclassical standard textbook model of labor supply and the job search theory both assume that individuals only choose employment over non-employment if the offered wage is larger than the reservation wage. If women and older workers on average suffer a greater difference between reservation wages and offered wages compared with men and younger workers, the employment probability of women and older workers will be lower. For example, age might have a stronger positive effect on reservation wages (e.g. owing to higher preference for leisure) than on offered wages (e.g. owing to depreciation of human capital), which decreases the average employment probability of older workers. For women, one might expect that leisure preferences and reservation wages would increase during motherhood, whereas productivity and, consequently, offered wages are not positively affected. Because of human capital depreciation, employment interruptions may even lead to lower wage offers and therefore hamper the integration of women and especially mothers in the labor market.

We use large-scale household panel data from Germany (GSOEP: German Socio-Economic Panel) to analyze average age and gender differences in reservation wages, entry wages as proxy for offered wages, preferred and actual working hours, and leisure and job satisfaction. In the context of reservation wages, we also make a methodological contribution by showing the importance of hourly information. Our analyses focus on the years 2007 and 2008, because these are the only years for which we can compute hourly reservation wages. Previous research has largely used weekly or monthly reservation wages, which are not suitable for analyzing age and gender differences. If, for example, female and older workers prefer to work fewer hours than men and younger workers, their weekly or monthly reservation income is, ceteris paribus, lower. This might even be the case if their hourly reservation wages are larger but not large enough to compensate for fewer working hours. In our empirical analysis, we find that older workers indeed have larger hourly reservation wages but lower monthly reservation wages owing to their preference for working fewer hours. The estimated age effects are greater for women than men. We further find that the presence of children in the household increases reservation wages and reduces the supplied working hours of women, whereas no significant effects are detected for men. Although our econometric analysis is largely descriptive, we find consistent evidence that older workers and mothers have higher preferences for leisure and higher reservation wages, which might explain the observed gaps in employment rates.

This paper is structured as follows. The next section summarizes the theoretical background derived from labor supply and job search models as well as previous empirical studies. Section 3 describes the data, variables, and methods. The regression results are presented in Sect. 4. The paper concludes with a summary and discussion of the findings in Sect. 5.

\section{Theory and previous research on reservation wages}

\subsection{Labor supply and job search}

In this section we present two standard textbook models of labor supply decisions. First, we present the neoclassical labor supply model (e.g. Borjas 2009, Chap. 2) and, second, a basic on-the-job search model (e.g. Cahuc and Zylberberg 2004, Chap. 3). Each of them is enriched with a discussion of age and gender-related effects on reservation wages. 
In the neoclassical model, reservation wages are defined as the marginal rate of substitution between leisure and consumption at the initial non-working income and no hours of work. We assume that individuals are heterogeneous with respect to age and gender, which affects reservation wages and individual labor supply decisions. Following several authors such as Lazear (1979, 1986), Heckman (1974) and Chang (1991), we interpret reservation wages as the shadow price of leisure. Lazear (1979) assumes in his deferred compensation model that reservation wages increase with age. Heckman (1974), Lazear (1986), and Chang (1991) discuss different shapes of reservation wage profiles in the context of lifecycle models and retirement decisions. In the traditional family model, men should offer more hours of working time than women. This may be explained by the necessity to earn additional household income for the family. As regards women, we assume there are differences between mothers and childless women. Non-mothers decide between leisure and working time, whereas mothers take additional time exposures into consideration for household production (e.g. care for their children; Browning 1992). Mothers with high wages, however, have the opportunity to buy childcare on the market. ${ }^{1}$ In general, however, mothers have a lower time budget which they can allocate to market work. Moreover, mothers might have higher preferences for non-market work and leisure because they want to spend time with their children. Both considerations lead to a larger marginal rate of substitution between leisure time and consumption goods and, consequently, to mothers' higher reservation wages.

Concerning age, we offer the following considerations. Younger people are likely to have lower reservation wages than older ones because of a lower level of endowment of consumption goods. Older individuals, on the other hand, can lower their labor supply or even retire, because of a higher endowment of consumption goods. After a long working life they should have a higher level of non-market income or wealth and should have accumulated a stock of goods (e.g. lifetime savings, real estate, financial assets, legacies, greater unemployment benefit entitlement). These larger endowments should lead to a larger marginal rate of substitution between leisure time and consumption goods for older individuals. It also seems likely that older individuals have higher preference for leisure, because they might want to utilize their stock of accumulated goods and might already be exhausted by long working careers. If a partner has already retired from work, an older non-employed person might want to spend more time with him/her. In the words of Gordon and Blinder (1980, p. 278), “(...) as people age, their preferences may shift in favor of leisure and

\footnotetext{
${ }^{1}$ Miller (2011) notes that highly educated women benefit from delaying childbirth in terms of higher wages and better career opportunities.
}

against work," from which it follows that older individuals are likely to have higher reservation wages and, consequently, lower employment rates.

For the job search model we will follow the influential works of Mortensen (1970) and McCall (1970). Surveys like those by Mortensen and Pissarides (1999) and Rogerson et al. (2005) describe different model-specific options like on-the-job-search models, matching theories or labor market policy implications. ${ }^{2}$

Once again, we focus on age and gender effects on reservation wages. First, public transfers raise the non-working income and lead ceteris paribus to higher reservation wages. Unemployment benefits for instance depend on payoffs from the last job. Although wages increase over the lifespan, older individuals receive higher unemployment benefits and non-working income increases as well. The reservation wages of older individuals are higher and the duration of search is longer. Women on average face fewer transfers than men because of a higher share in part-time employment with lower income. In this context non-working income is smaller and female reservation wages are lower. Because mothers receive additional child-related public compensation transfers, non-working income and, consequently, reservation wages are higher. This leads to a longer duration of search for mothers. Hunt (1995) and Steiner (2001) calculate hazard rates for Western Germany based on GSOEP data. Hunt shows that an increase in entitlement to unemployment compensation increases the duration of unemployment. Steiner argues that the older non-employed and women with young children have lower probabilities of being employed than young men or childless women. Fitzenberger and Wilke (2010) confirm the findings using German employment data. They show an overall increase in duration of non-employment, but not for job searchers between jobs. Kunze and Troske (2012) analyze the effect of plant closures on job-search behavior. Using Western German social security data, they find that women of fertile age have the lowest job search intensity, but gender differences in displacement time are statistically different only for younger women, with an exception around the age of 55 . Women younger than 25 and in the mid-forties have wage losses from 5 to 8 percent after re-employment. ${ }^{3}$ As regards Western Germany many

\footnotetext{
${ }^{2}$ Black (1995) adduces an enriched search model with firm discrimination. In the model there is one firm which does not hire one of two workers, because of distaste. There is another firm which employs both workers equally. The model shows that the existence of a discriminating firm on the market leads to higher search costs and lower reservation wages for the discriminated worker. Because of monopsonic market power, the non-discriminating firm offers lower market wages to this worker, as well. The discriminated worker has to accept poorer job matches with lower market wages, and lower job satisfaction. This model shows why minority groups such as older or female individuals are limited in terms of their labor supply decision.

${ }^{3}$ Kunze and Troske (2007) analyze the effects of US plant closures. Using National Longitudinal Survey of Youth data (NLSY), they report
} 
authors discuss wage losses for mothers returning to work. Schönberg and Ludsteck (2007), Sommerfeld (2009), and Beblo et al. (2009) report a drop in wages of around 10 to 20 percent per year, whereas Erjnaes and Kunze (2011) report 3 to 6 percent. Schönberg and Ludsteck (2007) show that extension of maternity leave increases delay in returning to work.

According to Hutchens (1988), older employees have a smaller range of career possibilities than younger people. Chan and Stevens (2001) show for the USA that older individuals have low probabilities of being re-employed after job loss. We further assume that ability to use modern information technologies and career networks can differ for older individuals and for women. Less access to formal and informal information concerning job offers reduces reservation wages. Men and women should have equal ability in terms of using information technologies. According to Schleife (2006), however, older people have poorer computer skills than younger people. Higher search costs reduce non-working income and lead to declining reservation wages. The quantity and the quality of career networks can influence the job offer rate. A larger network may lead to more contacts with firms and more job offers. A betterquality network should lead to better information concerning specific firms and their job openings and characteristics. Search costs should decline, because of better matching quality and fewer contacts with firms. Cappellari and Tatsiramos (2010) show that both network effects exist. The number of employed friends increases the probability of reemployment. These jobs are better paid and have lower layoff risks. We assume that the career network increases in the early years of working life and shrinks near retirement age. Therefore, older job searchers should have smaller networks than younger people. Women may have smaller network groups among the working population, as well. This may apply particularly to mothers who have been not employed owing to family responsibilities.

In the light of the above, older individuals, women, and especially mothers may report higher reservation wages and may be less effective in finding jobs. Mothers may be timeconstrained because of childcare arrangements and experience wage losses after returning to work. Older individuals may turn towards leisure activities because of higher endowment levels and shifting preferences.

\subsection{Previous empirical findings}

A large part of the theoretical and empirical literature on reservation wages is concerned with macroeconomic aspects

longer search time for women of fertile age than for women with additional children. Search behavior of older workers was not observed. such as unemployment rates and public unemployment insurances (Shimer and Werning 2007; Ljungqvist and Sargent 2008), which are beyond the scope of this paper. Therefore, we summarize only selected empirical studies that are of special relevance here (see Table 2).

A review of the literature reveals that most authors use monthly information concerning reservation wages [Kiefer and Neumann (1979) and Feldstein and Poterba (1984) for the United States; Maani and Studenmund (1986) for Chile; Jones (1989) for Great Britain; Gorter and Gorter (1993) for the Netherlands]. We provide a more detailed review for Germany. Franz (1982) shows a positive effect of public unemployment compensation on unemployment duration in Western Germany. Schmidt and Winkelmann (1993) use official unemployment data for Western Germany to show a positive effect on male reservation wages but no effect on socio-demographic variables. Several studies use monthly reservation wages of West Germany GSOEP data. Prasad (2001, 2004) reports mixed results for family status and children. Age is limited to 55 years. Prasad (2001) shows that marriage or children lower reservation wages, whereas higher education raises it. Because of a squared function for age, reservation wages increase in the early years and decline around the age of forty. Prasad (2004) presents similar results for age groups and higher reservation wages of married men. Children have a positive effect only on reservation wages for men, not women. Christensen (2005) shows that reservation wages are higher than the last market wages before non-employment. They do not decline with duration of unemployment. This finding suggests a stationary level of reservation wages over time. Christensen reports u-shaped age profiles separately for men and women. Pannenberg (2010) shows that risk aversion and reservation wages are negatively correlated.

We prefer the use of hourly information because of a possible bias in the monthly variable. Technically speaking, monthly wages include both the hourly wage and the number of working hours. This result of optimization may be influenced by the same variables but hypothetically not in the same direction. Unfortunately, only a few sources offer this information. In this context our paper clearly illustrates substantial differences in the measurement of working time. As far as we know, only the latest research uses hourly information, with the exception of Gordon and Blinder (1980). They calculate hourly reservation wages using wage information from the Longitudinal Retirement History Survey (LRHS). Bloemen and Stancanelli (2001) use the Dutch Socio-Economic Panel (SEP) to show a positive effect of wealth on reservation wages, whereby reservation wages increase until the age of 38 and decline later. Addison et al. (2009) use data from the European Community Household Panel (ECHP) and use cross-country information to investigate a positive relation between unemployment insurance and reservation wages in 13 countries. Most of them have 
Table 2 Chronological overview of previous studies on reservation wages

\begin{tabular}{llll}
\hline Study: author & $\begin{array}{l}\text { Data: country, source, } \\
\text { years }\end{array}$ & $\begin{array}{l}\text { Reservation wages } \\
\text { variables, methods }\end{array}$ & Findings \\
\hline
\end{tabular}

Kiefer and Neumann (1979)

Gordon and Blinder (1980)

Franz (1982)

Feldstein and Poterba (1984)

Maani and Studenmund (1986)

Jones (1989)

Schmidt and Winkelmann (1993)

Gorter and Gorter (1993) Netherlands, SEP, 1985-1987

Bloemen and Stancanelli Netherlands, SEP, (2001) 1987-1990

Prasad (2001)

Prasad (2004)

Christensen (2005)

Addison et al. (2009)

Brown et al. (2010)

Pannenberg (2010)

Brown et al. (2011)

Krueger and Mueller (2011) Register, 1976$$
\text { 1984-1997 }
$$
1984-2000 1991-2004 2004-2006 1991-2007
USA, Survey, 1969-1973

USA, LRHS, 1969-1973 Maximum-Likelihood

Reservation Wages hourly (calculated), OLS

Germany, Unemployment Reservation Wages monthly, OLS

USA, Current Population Reservation Wages Survey, May 1976 monthly, OLS

Chile, Survey, 1981-1982 Reservation Wages monthly, OLS, 2SLS

Great Britain, Economist Reservation Wages Intelligence Unit, 1982 monthly, OLS

Germany, Federal Reservation Wages Secretary of Labor, 1978 monthly, OLS

Reservation Wages monthly, OLS, 2SLS

Reservation Wages monthly/hourly, OLS, IV

Reservation Wages monthly, OLS

Reservation Wages monthly, OLS

Germany, GSOEP,

Reservation Wages monthly, OLS, IV

13 European Countries, ECHP, 1994-1999

Great Britain, BHPS,

Germany, GSOEP,

Great Britain, BHPS,

USA (New Jersey), Survey, 24 weeks in 2009-2010
Reservation Wages hourly, RE, FE

Reservation Wages, hourly, OLS

Reservation Wages monthly, OLS, FE

Reservation Wages hourly, Oaxaca Decomposition

Reservation Wages hourly, OLS, probit
Reservation Wages increase with Age and bad Health, decline with Marriage, mixed Effects for Children (Sample: only Men).

Unemployment Compensations increase over Duration of Unemployment.

Unemployment Insurances increase Duration of Unemployment.

Reservation Wages decline over Duration of Unemployment (Sample: only Men).

Last Wages influence Reservation Wages positive. Higher Reservation Wages for Men, especially for Husbands.

Reservation Wages decline with Duration of Unemployment. Higher Reservation Wages for Men. No Significance for Age.

Reservation Wages increase with Age and educational Level.

Inverse u-shaped Effect of Age on Reservation Wages. Wealth increase Reservation Wages.

Inverse u-shaped Effect of Age on Reservation Wages. Marriage and Children lower Reservation Wages.

Higher Reservation Wages for married Men. Children increase only Men's Reservation Wages.

Reservation Wages constant over Duration of Unemployment. Reservation Wages higher than last Market Wages.

Reservation Wages constant with Duration of Unemployment. Unemployment Benefits increase Reservation Wages.

Reservation Wages and Market Wages increase with Age, decline after Age 55. No Effect of Health on Reservation Wages (Sample: only Men).

Risk Aversion lower Reservation Wages. Reservation Wages lower with Duration of Unemployment.

Reservation Wages is higher for Men. Reservation Wages lower with Duration of Unemployment.

Reservation Wages increase with Age, decline after Age 50. Reservation Wages close to last Market Wages. Amount of Job Search Time decline over Unemployment Duration. reservation wages that are constant over the duration of nonemployment. Information concerning reservation wages is not always included for every country and every year. The coefficients for age and gender are not reported. The German data, for example, are taken from special administrative data for two years. Using the British Household Panel Survey (BHPS), Brown et al. (2010) compare weekly reservation wages and market wages, but only for men. Both types of wages increase with age, but decline after the age of 55. In the same data, Brown et al. (2011) find lower hourly reservation wages among women, which is interpreted as a positive gender reservation wage gap. Effects of gender and family aspects such as motherhood explain some of the gap. Krueger and Mueller (2011) use hourly reservation wages from weekly interviews based on detailed administrative unemployment information from the state of New Jersey to show that reservation wages are stable in younger and middle ages, but decline after the age of 50 . 


\section{Data and variables}

We use representative German household survey data from the German Socio-Economic Panel (GSOEP; Wagner et al. 2007). As we are interested in non-employed and employed individuals, all pensioners, individuals in military or community service, apprenticeships or training, those who are self-employed or freelancers, and individuals working in family businesses have been excluded from the data. The sample is further restricted to observations of those between 18 and 65 years of age. The age of 18 is the German age of legal majority and 65 is the legal retirement age. Our sample is limited to the years 2007 and 2008 because our variable of main interest, hourly reservation wages, cannot be computed in previous years from the GSOEP data. The sample includes 3812 observations of 3022 individuals, with 1905 observations of 1522 non-employed individuals concerning reservation wages (617 men and 905 women) and 1907 observations of 1757 employed individuals concerning entry wages ( 819 men and 938 women).

In our empirical analysis we compare the results from regressions for log hourly reservation wages and log hourly entry wages to obtain insights into age and gender differences as potential explanations for differences in observed employment rates. We further compare these results with estimates for log monthly reservation and entry wages in order to evaluate any potential specification bias that might lead to wrong conclusions. Additional regressions for preferred and actual weekly working hours, leisure and job satisfaction are estimated to analyze whether differences in preferences for leisure rather than work are the reason for age and gender differences in reservation wages. Equation (1) presents the basic estimation framework, in which $Y_{i t}$ represents the different dependent variables mentioned above for individual $i$ in year $t$. The main explanatory variables of interest are age groups (18 to 25 years as reference, 26-35, 36-45, 46-55, 56-65) with coefficients $\alpha{ }^{4} X_{i t}$ denotes a vector of additional explanatory variables with the coefficients $\beta .^{5} \varepsilon_{i t}$ is the usual remaining error term. A list of the variables, short definitions, and descriptive statistics for the complete sample are displayed in Table 3.

\footnotetext{
${ }^{4}$ Owing to non-linearity and in order to make interpretation of the results easier, we decided to use age groups instead of a specification with continuous age and higher order polynomials. We also experimented with different definitions of age groups. The results are not sensitive to this definition.

${ }^{5}$ Owing to high collinearity between age and work experience, we do not include work experience in the regressions. We have also estimated specifications with an additional control variable for differences in tenure if possible (only for employed workers in hours and satisfaction regressions). Tenure itself has only a small impact on the outcome variables and does not significantly affect the estimated parameters when compared with our preferred specification without tenure. For consistency reasons, we chose to present the same specifications (without tenure) across all regressions and subsamples.
}

$$
\begin{aligned}
Y_{i t}= & \alpha_{1}+\alpha_{2} A g e_{i t}^{[26,35]}+\alpha_{3} A g e_{i t}^{[36,45]}+\alpha_{4} A g e_{i t}^{[46,55]} \\
& +\alpha_{5} A g e_{i t}^{[56,65]}+X_{i t} \beta+\varepsilon_{i t}
\end{aligned}
$$

Reservation wages are asked about in the GSOEP questionnaire in this way: "How high would your net income or salary have to be for you to take a position offered to you?" This question is asked to individuals without paid employment, but who intend to be engaged in paid employment in the near future. To get hourly information we use a question concerning the preferred weekly working hours of the non-employed, which is included in the survey since 2007: "In your opinion how many hours a week would you have to work to earn this net income?" Entry wages are calculated only for employed individuals with less than one year of tenure. For all wage variables we use a logarithm. Because of implausible interpretation, we drop all observations with wages below one Euro.

Concerning the working time aspects, we compare preferred and actual weekly working hours. We have information about job searchers' preferred hours and for employed individuals can compare their preferred with the actual working time. We also perform regressions for satisfaction with leisure and job that might indicate shifting preferences. Although job satisfaction is only given for employed individuals, satisfaction with leisure is available for all individuals. The satisfaction variables use a Likert scale of ascending order from zero (very unhappy) to 10 (very happy).

We use a set of socioeconomic determinants as explanatory variables. We focus on age and gender aspects and the influence of children on labor supply. Additionally, we control for household income, education, state of health, German citizenship, regional unemployment rate, years, and federal states. We use five age groups (18 to 25 years as reference, 26-35, 36-45, 46-55, 56-65) to allow for nonlinear age effects. In regressions for the complete sample of men and women, we also include a dummy variable for being female. Another dummy variable accounts for the presence of children under the age of 16 in a household. The household income is used as the log of the adjusted monthly net household income. It includes labor and non-labor income of all household members. Hence, it is a proxy for non-labor income of non-employed individuals and wealth in general. In order to control for differences in education we include secondary school certificates as well as vocational and college degrees. The subjective state of health is measured in three categories: good, normal, and bad. The regressions further take into account German citizenship. In the regressions concerning satisfaction with leisure and work, we control additionally for overall life satisfaction in order to reduce potential omitted variable bias stemming from unobserved heterogeneity.

The regional unemployment rate in the month of the interview is included to control for state and month-specific 
Table 3 Variable list and definitions

\begin{tabular}{|c|c|c|}
\hline Variable & Definition & $\begin{array}{l}\text { Mean (Std. dev.) for } \\
\text { complete sample }\end{array}$ \\
\hline Reservation Wages hourly (non-employed) & $\begin{array}{l}\text { log Reservation Wages per Hour in Euro. (Reservation Wages } \\
\text { monthly/(4.25* Preferred weekly Working Hours)) }\end{array}$ & $2.028(0.438)$ \\
\hline Reservation Wages monthly (non-employed) & log Reservation Wages per Month in Euro & $6.895(0.532)$ \\
\hline Entry Wages hourly (employed) & $\begin{array}{l}\text { log Entry Wages per Hour (only tenure less one Year). (Wages } \\
\text { monthly/(4.25*Actual weekly Working Hours) }\end{array}$ & $1.884(0.503)$ \\
\hline Entry Wages monthly (employed) & log Entry Wages per Month (only tenure less one Year) & $6.748(0.771)$ \\
\hline Preferred Working Hours (non-employed) & Preferred Number of weekly Working Hours (non-employed) & $33.425(11.415)$ \\
\hline Preferred Working Hours (employed) & Preferred Number of weekly Working Hours (employed) & $34.035(11.261)$ \\
\hline Actual Working Hours (employed) & Real Number of weekly Working Hours (employed) & $35.014(14.854)$ \\
\hline Leisure Satisfaction & Satisfaction with Leisure: Scale 0 to 10 (0:low, 10:high) & $6.654(2.239)$ \\
\hline Job Satisfaction (employed) & Satisfaction with Job: scale 0 to 10 (0:low, 10:high) & $6.592(2.602)$ \\
\hline Age: $18-25$ Years & Dummy for Age: 18-25 Years (Reference) & \\
\hline Age: $26-35$ Years & Dummy for Age: $26-35$ Years & $0.282(0.450)$ \\
\hline Age: $36-45$ Years & Dummy for Age: $36-45$ Years & $0.256(0.436)$ \\
\hline Age: $46-55$ Years & Dummy for Age: 46-55 Years & $0.176(0.381)$ \\
\hline Age: $56-65$ Years & Dummy for Age: $56-65$ Years & $0.064(0.244)$ \\
\hline Female & Dummy for being female & $0.562(0.496)$ \\
\hline Children & Dummy for having Children under Age of 16 in Household & $0.437(0.496)$ \\
\hline Secondary School & Dummy for having a Secondary School Degree ("Unterstufe") (Reference) & \\
\hline Intermediate School & Dummy for having an Intermediate School Degree (“Mittelstufe”) & $0.353(0.478)$ \\
\hline Upper School & Dummy for having an Upper School Degree ("Oberstufe”) & $0.274(0.446)$ \\
\hline Vocational Degree & Dummy for having a Vocational Degree & $0.639(0.480)$ \\
\hline College Degree & Dummy for having a College Degree & $0.159(0.366)$ \\
\hline Health: good & Dummy for State of Health: good (Reference) & \\
\hline Health: normal & Dummy for State of Health: normal & $0.287(0.453)$ \\
\hline Health: bad & Dummy for State of Health: bad & $0.131(0.337)$ \\
\hline Household Income & log adjusted Household Income in Euro & $7.651(0.631)$ \\
\hline German & Dummy for having German Citizenship & $0.927(0.260)$ \\
\hline Unemployment Rate & $\begin{array}{l}\text { German Federal States' unemployment Rate (Information per State and } \\
\text { Month, for Rhineland-Palatinate/Saarland information per Regional } \\
\text { Directorate and Month) }\end{array}$ & $11.399(4.606)$ \\
\hline Year 2008 & Dummy for Year 2008 & $0.472(0.499)$ \\
\hline Overall Life Satisfaction & Overall Life Satisfaction: Scale 0 to 10 (0:low, 10:high) & $6.626(1.974)$ \\
\hline State: Schleswig-Holstein & $\begin{array}{l}\text { Dummy for Federal State: Schleswig-Holstein (“Schleswig-Holstein”) } \\
\text { (Reference) }\end{array}$ & \\
\hline State: Hamburg & Dummy for Federal State: Hamburg (“Hamburg”) & $0.015(0.121)$ \\
\hline State: Lower Saxony & Dummy for Federal State: Lower Saxony (“Niedersachsen”) & $0.092(0.290)$ \\
\hline State: Bremen & Dummy for Federal State: Bremen (“Bremen”) & $0.007(0.084)$ \\
\hline State: North Rhine-Westphalia & $\begin{array}{l}\text { Dummy for Federal State: North Rhine-Westphalia } \\
\text { ("Nordrhein-Westfalen") }\end{array}$ & $0.183(0.387)$ \\
\hline State: Hesse & Dummy for Federal State: Hesse (“Hessen”) & $0.067(0.251)$ \\
\hline State: Rhineland-Palatinate/Saarland & $\begin{array}{l}\text { Dummy for Federal State: Rhineland-Palatinate/Saarland } \\
\text { ("Rheinland-Pfalz/Saarland") }\end{array}$ & $0.048(0.215)$ \\
\hline State: Baden-Wuerttemberg & Dummy for Federal State: Baden-Wuerttemberg (“Baden-Württemberg”) & $0.083(0.275)$ \\
\hline State: Bavaria & Dummy for Federal State: Bavaria (“Bayern”) & $0.130(0.336)$ \\
\hline State: Berlin & Dummy for Federal State: Berlin (“Berlin”) & $0.047(0.211)$ \\
\hline State: Saxony & Dummy for Federal State: Saxony (“Sachsen”) & $0.098(0.297)$ \\
\hline State: Mecklenburg-Western Pomerania & $\begin{array}{l}\text { Dummy for Federal State: Mecklenburg-Western Pomerania } \\
\text { ("Mecklenburg-Vorpommern") }\end{array}$ & $0.033(0.177)$ \\
\hline State: Brandenburg & Dummy for Federal State: Brandenburg (“Brandenburg”) & $0.062(0.241)$ \\
\hline State: Saxony-Anhalt & Dummy for Federal State: Saxony-Anhalt (“Sachsen-Anhalt”) & $0.047(0.212)$ \\
\hline State: Thuringia & Dummy for Federal State: Thuringia (“Thüringen”) & $0.056(0.230)$ \\
\hline
\end{tabular}

Notes: GSOEP 2007/2008. 3812 observations in complete sample 
Table 4 Means of outcome variables of interest by age groups

\begin{tabular}{|c|c|c|c|c|c|c|c|c|c|c|}
\hline & $\begin{array}{l}\text { Age } \\
\text { categories }\end{array}$ & $\begin{array}{l}\text { Reservation } \\
\text { wages } \\
\text { (hourly) }\end{array}$ & $\begin{array}{l}\text { Entry } \\
\text { wages } \\
\text { (hourly) }\end{array}$ & $\begin{array}{l}\text { Reservation } \\
\text { wages } \\
\text { (monthly) }\end{array}$ & $\begin{array}{l}\text { Entry } \\
\text { wages } \\
\text { (monthly) }\end{array}$ & $\begin{array}{l}\text { Preferred } \\
\text { hours (non- } \\
\text { employed) }\end{array}$ & $\begin{array}{l}\text { Preferred } \\
\text { hours (em- } \\
\text { ployed) }\end{array}$ & $\begin{array}{l}\text { Actual } \\
\text { hours }\end{array}$ & $\begin{array}{l}\text { Leisure } \\
\text { satisfaction }\end{array}$ & $\begin{array}{l}\text { Job } \\
\text { satisfaction }\end{array}$ \\
\hline \multirow[t]{6}{*}{ All } & 18-25 Years & 7.78 & 6.08 & 1200.93 & 812.10 & 36.79 & 33.91 & 33.20 & 7.12 & 6.91 \\
\hline & 26-35 Years & 8.86 & 7.70 & 1129.11 & 1163.28 & 32.43 & 35.50 & 37.19 & 6.50 & 7.00 \\
\hline & 36-45 Years & 8.77 & 8.04 & 1082.00 & 1197.85 & 30.88 & 32.28 & 33.98 & 6.45 & 6.38 \\
\hline & 46-55 Years & 8.52 & 7.70 & 1080.06 & 1168.44 & 33.36 & 33.81 & 34.38 & 6.47 & 6.06 \\
\hline & 56-65 Years & 8.46 & 7.91 & 1172.19 & 1208.39 & 34.22 & 35.13 & 35.77 & 7.02 & 5.64 \\
\hline & Total: & 8.48 & 7.48 & 1129.05 & 1106.28 & 33.43 & 34.04 & 35.01 & 6.65 & 6.59 \\
\hline \multirow[t]{6}{*}{ Men } & 18-25 Years & 7.80 & 6.22 & 1288.32 & 913.43 & 38.99 & 36.47 & 36.64 & 7.27 & 6.75 \\
\hline & 26-35 Years & 9.17 & 7.58 & 1500.55 & 1394.66 & 39.82 & 40.18 & 43.68 & 6.58 & 7.01 \\
\hline & 36-45 Years & 8.50 & 9.05 & 1417.45 & 1713.81 & 39.75 & 39.89 & 43.77 & 6.45 & 6.12 \\
\hline & 46-55 Years & 8.79 & 8.57 & 1292.90 & 1649.52 & 38.13 & 40.07 & 42.29 & 6.14 & 5.77 \\
\hline & 56-65 Years & 8.75 & 8.58 & 1326.40 & 1432.53 & 36.78 & 37.71 & 39.95 & 6.76 & 5.67 \\
\hline & Total: & 8.52 & 7.92 & 1360.34 & 1425.56 & 38.87 & 39.21 & 41.88 & 6.65 & 6.44 \\
\hline \multirow[t]{6}{*}{ Women } & $18-25$ Years & 7.76 & 5.97 & 1121.38 & 732.37 & 34.79 & 31.90 & 30.49 & 6.99 & 7.04 \\
\hline & 26-35 Years & 8.71 & 7.82 & 943.98 & 942.28 & 28.74 & 31.02 & 31.00 & 6.44 & 6.99 \\
\hline & 36-45 Years & 8.89 & 7.27 & 926.30 & 807.31 & 26.76 & 26.53 & 26.57 & 6.45 & 6.59 \\
\hline & 46-55 Years & 8.29 & 7.00 & 895.89 & 786.89 & 29.22 & 28.84 & 28.11 & 6.74 & 6.30 \\
\hline & 56-65 Years & 8.02 & 6.56 & 931.07 & 760.12 & 30.22 & 29.99 & 27.41 & 7.47 & 5.58 \\
\hline & Total: & 8.45 & 7.10 & 968.69 & 828.06 & 29.65 & 29.53 & 29.03 & 6.66 & 6.72 \\
\hline
\end{tabular}

differences in labor market conditions, which is an important issue (Sestito and Viviani 2011). ${ }^{6}$ Because of regional aggregations in the GSOEP data, Rhineland-Palatinate and Saarland are treated as one region. Here we use information from the regional directorate of the Federal Employment Agency. In order to control for further regional differences, we include dummy variables for all German federal states. A dummy variable for the year 2008 is included to control for aggregated time effects such as inflation rate.

Before we start our regression analyses in the next section, we present the means of the outcome variables of interest by age group category in Table 4 . It can be seen that there are gender-specific differences for age. For instance, preferred and actual working hours for males are inverse ushaped, whereas the female pattern is slightly u-shaped.

\section{Results of regression analyses}

In the first part of our empirical analysis, we estimate loglinear earnings functions in order to evaluate age and gender differences in reservation and entry wages. As information

\footnotetext{
${ }^{6}$ This information is taken from a long time series of German federal unemployment statistics published on the homepages of the German Federal Statistical Office (http://www.destatis.de).
}

about working hours for stated monthly reservation income is not available before the year 2007, we estimate pooled cross-section OLS (ordinary least squares) regressions for the years 2007 and 2008. First, we turn to our main results for $\log$ hourly reservation and log hourly entry wages. Afterwards, we estimate further regressions for log monthly reservation and log monthly entry wages in order to show that the monthly information is unsuitable for some purposes as the results can lead to wrong conclusions.

The regression results for log hourly reservation and $\log$ hourly entry wages are displayed in Table 5. The first two columns comprise the results for the complete sample. It can be seen that hourly reservation and entry wages increase with age, but that the age effect on reservation wages is greater than that on entry wages. This finding is consistent with our assumption that older workers may remain voluntarily non-employed because their reservation wages are larger than the potential wages for which our entry wages serve as proxies. Women have on average about 6 percent lower reservation wages than men. As the entry wages of women are even lower (by approximately 13 percent), the gap between reservation and entry wages is larger for women, which might partly explain the gender gap in employment rates. The results further indicate a positive correlation between reservation and entry wages, on the one 
Table 5 Log hourly reservation and log hourly entry wages

\begin{tabular}{|c|c|c|c|c|c|c|}
\hline & \multicolumn{2}{|l|}{ All } & \multicolumn{2}{|l|}{ Men } & \multicolumn{2}{|l|}{ Women } \\
\hline & $\begin{array}{l}\text { Reservation } \\
\text { wages }\end{array}$ & $\begin{array}{l}\text { Entry } \\
\text { wages }\end{array}$ & $\begin{array}{l}\text { Reservation } \\
\text { wages }\end{array}$ & $\begin{array}{l}\text { Entry } \\
\text { wages }\end{array}$ & $\begin{array}{l}\text { Reservation } \\
\text { wages }\end{array}$ & $\begin{array}{l}\text { Entry } \\
\text { wages }\end{array}$ \\
\hline Age: $26-35$ Years (Ref: 18-25) & $\begin{array}{l}0.1472 * * * \\
(0.0288)\end{array}$ & $\begin{array}{l}0.1315^{* * * *} \\
(0.0298)\end{array}$ & $\begin{array}{l}0.1983 * * * \\
(0.0440)\end{array}$ & $\begin{array}{l}0.1362 * * * \\
(0.0448)\end{array}$ & $\begin{array}{l}0.0901 * * \\
(0.0371)\end{array}$ & $\begin{array}{l}0.1572 * * * \\
(0.0412)\end{array}$ \\
\hline Age: $36-45$ Years & $\begin{array}{l}0.1725 * * * \\
(0.0302)\end{array}$ & $\begin{array}{l}0.1659 * * * \\
(0.0325)\end{array}$ & $\begin{array}{l}0.1835 * * * \\
(0.0489)\end{array}$ & $\begin{array}{l}0.2487 * * * \\
(0.0492)\end{array}$ & $\begin{array}{l}0.1362^{* * * *} \\
(0.0394)\end{array}$ & $\begin{array}{l}0.1378 * * * \\
(0.0446)\end{array}$ \\
\hline Age: $46-55$ Years & $\begin{array}{l}0.1752 * * * \\
(0.0345)\end{array}$ & $\begin{array}{l}0.1354 * * * \\
(0.0373)\end{array}$ & $\begin{array}{l}0.1849 * * * \\
(0.0526)\end{array}$ & $\begin{array}{l}0.1898 * * * \\
(0.0543)\end{array}$ & $\begin{array}{l}0.1473 * * * \\
(0.0461)\end{array}$ & $\begin{array}{l}0.1055^{* *} \\
(0.0496)\end{array}$ \\
\hline Age: 56-65 Years & $\begin{array}{l}0.2268 * * * \\
(0.0425)\end{array}$ & $\begin{array}{l}0.1948 * * * \\
(0.0529)\end{array}$ & $\begin{array}{l}0.2341 * * * \\
(0.0570)\end{array}$ & $\begin{array}{l}0.2360 * * * \\
(0.0691)\end{array}$ & $\begin{array}{l}0.2142^{* * * *} \\
(0.0695)\end{array}$ & $\begin{array}{l}0.1458 * \\
(0.0789)\end{array}$ \\
\hline Female & $\begin{array}{l}-0.0660 \text { *** } \\
(0.0202)\end{array}$ & $\begin{array}{l}-0.1302 * * * \\
(0.0206)\end{array}$ & & & & \\
\hline Children & $\begin{array}{l}0.0365 \\
(0.0227)\end{array}$ & $\begin{array}{l}0.0671 * * * \\
(0.0231)\end{array}$ & $\begin{array}{l}0.0036 \\
(0.0358)\end{array}$ & $\begin{array}{l}0.1220 * * * \\
(0.0328)\end{array}$ & $\begin{array}{l}0.0680 * * \\
(0.0295)\end{array}$ & $\begin{array}{l}0.0165 \\
(0.0322)\end{array}$ \\
\hline $\begin{array}{l}\text { School: Intermediate School } \\
\text { (Ref: Secondary School) }\end{array}$ & $\begin{array}{l}-0.0170 \\
(0.0230)\end{array}$ & $\begin{array}{l}0.0733 * * * \\
(0.0269)\end{array}$ & $\begin{array}{l}-0.0546 \\
(0.0345)\end{array}$ & $\begin{array}{l}0.0577 \\
(0.0382)\end{array}$ & $\begin{array}{l}-0.0073 \\
(0.0315)\end{array}$ & $\begin{array}{l}0.0755 * * \\
(0.0376)\end{array}$ \\
\hline School: Upper School & $\begin{array}{l}0.1865 * * * \\
(0.0288)\end{array}$ & $\begin{array}{l}0.1935^{* * *} \\
(0.0318)\end{array}$ & $\begin{array}{l}0.1998 * * * \\
(0.0471)\end{array}$ & $\begin{array}{l}0.1573 * * * \\
(0.0480)\end{array}$ & $\begin{array}{l}0.1786^{* * * *} \\
(0.0367)\end{array}$ & $\begin{array}{l}0.1976 * * * \\
(0.0422)\end{array}$ \\
\hline Vocational Degree & $\begin{array}{l}-0.0254 \\
(0.0223)\end{array}$ & $\begin{array}{l}0.0135 \\
(0.0260)\end{array}$ & $\begin{array}{l}0.0420 \\
(0.0353)\end{array}$ & $\begin{array}{l}0.0344 \\
(0.0376)\end{array}$ & $\begin{array}{l}-0.0572 * * \\
(0.0289)\end{array}$ & $\begin{array}{l}-0.0160 \\
(0.0344)\end{array}$ \\
\hline College Degree & $\begin{array}{l}0.0654 * \\
(0.0338)\end{array}$ & $\begin{array}{l}0.1865^{* * * *} \\
(0.0337)\end{array}$ & $\begin{array}{l}-0.0214 \\
(0.0656)\end{array}$ & $\begin{array}{l}0.1962^{* * * *} \\
(0.0500)\end{array}$ & $\begin{array}{l}0.1099 * * * \\
(0.0388)\end{array}$ & $\begin{array}{l}0.1657 * * * \\
(0.0439)\end{array}$ \\
\hline Health: Normal (Ref: Good) & $\begin{array}{l}-0.0299 \\
(0.0229)\end{array}$ & $\begin{array}{l}-0.0030 \\
(0.0235)\end{array}$ & $\begin{array}{l}-0.0399 \\
(0.0391)\end{array}$ & $\begin{array}{l}-0.0376 \\
(0.0326)\end{array}$ & $\begin{array}{l}-0.0209 \\
(0.0285)\end{array}$ & $\begin{array}{l}0.0145 \\
(0.0327)\end{array}$ \\
\hline Health: Bad & $\begin{array}{l}-0.0729 * * * \\
(0.0282)\end{array}$ & $\begin{array}{l}-0.0324 \\
(0.0375)\end{array}$ & $\begin{array}{l}-0.0779 * \\
(0.0434)\end{array}$ & $\begin{array}{l}-0.0511 \\
(0.0684)\end{array}$ & $\begin{array}{l}-0.0735^{* *} \\
(0.0370)\end{array}$ & $\begin{array}{l}-0.0281 \\
(0.0440)\end{array}$ \\
\hline Household Income & $\begin{array}{l}0.0701 * * * \\
(0.0169)\end{array}$ & $\begin{array}{l}0.2054 * * * \\
(0.0225)\end{array}$ & $\begin{array}{l}0.0927 * * * \\
(0.0269)\end{array}$ & $\begin{array}{l}0.3390^{* * * *} \\
(0.0349)\end{array}$ & $\begin{array}{l}0.0549 * * \\
(0.0229)\end{array}$ & $\begin{array}{l}0.0981 * * * \\
(0.0283)\end{array}$ \\
\hline German & $\begin{array}{l}-0.0404 \\
(0.0438)\end{array}$ & $\begin{array}{l}0.1327 * * * \\
(0.0474)\end{array}$ & $\begin{array}{l}-0.0914 \\
(0.0664)\end{array}$ & $\begin{array}{l}0.1581 * * * \\
(0.0599)\end{array}$ & $\begin{array}{l}-0.0040 \\
(0.0579)\end{array}$ & $\begin{array}{l}0.1340 * \\
(0.0755)\end{array}$ \\
\hline Unemployment Rate & $\begin{array}{l}-0.0161 \\
(0.0166)\end{array}$ & $\begin{array}{l}-0.0085 \\
(0.0167)\end{array}$ & $\begin{array}{l}0.0121 \\
(0.0300)\end{array}$ & $\begin{array}{l}-0.0207 \\
(0.0223)\end{array}$ & $\begin{array}{l}-0.0356^{*} \\
(0.0188)\end{array}$ & $\begin{array}{l}0.0095 \\
(0.0249)\end{array}$ \\
\hline Year 2008 & $\begin{array}{l}0.0003 \\
(0.0359)\end{array}$ & $\begin{array}{l}-0.0218 \\
(0.0327)\end{array}$ & $\begin{array}{l}0.1059 \\
(0.0655)\end{array}$ & $\begin{array}{l}-0.0391 \\
(0.0446)\end{array}$ & $\begin{array}{l}-0.0683^{*} \\
(0.0406)\end{array}$ & $\begin{array}{l}-0.0111 \\
(0.0474)\end{array}$ \\
\hline Federal States & Yes & Yes & Yes & Yes & Yes & Yes \\
\hline Constant & $\begin{array}{l}1.6160 * * * \\
(0.2128)\end{array}$ & $\begin{array}{l}0.0938 \\
(0.2637)\end{array}$ & $\begin{array}{l}1.0572 * * * \\
(0.3470)\end{array}$ & $\begin{array}{l}-0.8232 * * \\
(0.3700)\end{array}$ & $\begin{array}{l}1.9041 * * * \\
(0.2694)\end{array}$ & $\begin{array}{l}0.6313^{*} \\
(0.3831)\end{array}$ \\
\hline$R^{2}$ & 0.1592 & 0.2635 & 0.1761 & 0.3746 & 0.1766 & 0.2023 \\
\hline Adjusted $R^{2}$ & 0.1458 & 0.2517 & 0.1442 & 0.3534 & 0.1548 & 0.1789 \\
\hline$F$-Test & 14.1749 & 20.8078 & 6.0783 & 16.5399 & 11.6065 & 8.6610 \\
\hline Number of observations & 1905 & 1907 & 780 & 888 & 1125 & 1019 \\
\hline Number of individuals & 1522 & 1757 & 617 & 819 & 905 & 938 \\
\hline
\end{tabular}

Notes: OLS, robust standard errors in parentheses

Levels of significance $* * * 1 \%$, * $5 \%$, *10\%, GSOEP 2007/2008 
hand, and the presence of children in the household, education, good health, and household income, on the other.

Owing to significant gender differences in the determinants of reservation and entry wages, our further discussion focuses on separate estimates for men and women. ${ }^{7}$ Columns three and four include the results for men and columns five and six those for women. The reservation wages of men do not significantly differ between the ages of 26 to 55 years but are significantly larger for men older than 55. Entry wages for older male workers increase by about the same amount. The results for women are quite different. Whereas their reservation wages strongly increase with age, their entry wages do not. An explanation for this finding may be that the age effects on preferences towards leisure and consumption do not significantly differ between men and women, which leads to small differences in the age effects on reservation wages. Entry wages, on the other hand, depend strongly on productivity, which is positively affected by on-the-job training and negatively by employment interruptions (depreciation of human capital). As women have more frequently interrupted employment biographies than men (owing to, e.g., family responsibilities), their entry wages on average do not increase with age as is the case for men. From our findings it follows that the increasing gap in employment rates might be a result of the increasing gap in the difference between reservation and entry wages.

Another interesting gender difference in the determinants of reservation and entry wages is the effect of the presence of children in the household. Whereas children have no effect on the reservation wages of men, they have significant positive effects on the reservation wages of women. This finding is consistent with our theoretical view that mothers have a tighter time budget, from which time can be allocated to market work, and higher preferences for leisure in order to care for their children. The consequence of these findings is a greater marginal rate of substitution between leisure and consumption and, hence, larger reservation wages for mothers. Fathers are also likely to have preferences for spending time with their children, which will increase their reservation wages. To compensate for the potential loss of mothers' income and to generate additional income for the children, however, fathers may have to search for jobs with higher intensity and reduce their reservation wages (Browning 1992, p. 1452). We further find that children have a positive effect on male entry wages but not on female entry wages. Although this finding might seem interesting at first glance, we attribute it largely to institutional arrangements of tax reductions and family subsidies, which are usually accounted

\footnotetext{
${ }^{7}$ In order to test for statistically different gender effects of age and children, we have also estimated the regressions with interaction terms between the female dummy and the explanatory variables of interest. The results show that most interaction terms are significant. The results are available from the authors on request.
}

for on the primary household earner's payroll. The overall results point to the dominance of the conservative family model, wherein the mother is concerned with family work and the father with market work.

To sum up our first piece of empirical evidence, the overall results indicate that women and especially mothers and older women have higher reservation wages but not higher entry wages. From this it follows that these groups have lower probabilities of choosing employment over nonemployment, which might explain their lower employment rates.

In the next step, we re-estimate the previous regressions using log monthly reservation and log monthly entry wages instead of hourly wages. Although most previous studies have used monthly reservation wages instead of hourly reservation wages, a conceptual problem arises. Because monthly reservation wages also include the preferred number of working hours which are likely to be influenced by the same variables, albeit not necessarily in the same direction, estimates are likely to be systematically biased and lead to wrong conclusions and policy recommendations. If compared with the results for hourly wages in Table 5, the results for monthly reservation and entry wages in Table 6 illustrate these erroneous conclusions. For example, age has negative effects on monthly reservation and entry wages and the presence of children reduces women's monthly reservation wages. The reason for these findings is, however, not negative effects on hourly reservation and entry wages but negative effects on working hours. Moreover, the gender gaps in reservation and entry wages are substantially larger for monthly than hourly data because women prefer to work on average fewer hours.

In order to validate our statements about the effects of age, gender, and presence of children on working hours, we estimate linear regressions for three outcome variables: (1) preferred weekly working hours by non-employed job searchers, (2) preferred weekly working hours by those who have started a new job within the last year, and (3) actual weekly working hours by those who have started a new job within the last year. The results in Table 7 show that preferred and actual working hours decrease with age and that the age effect is stronger for women than for men. We further find that women prefer on average to work fewer hours and actually work fewer hours than men. Women with children in the household prefer to work fewer hours and actually do so, whereas the presence of children does not significantly affect the labor supply of men. The overall findings indicate that women, especially mothers, and older workers voluntarily reduce their supplied working hours, which might be interpreted as the outcome of greater preferences for leisure.

According to the standard labor supply model discussed in the theory section, differences in reservation wages as well as in preferred and actual working hours might be an 
Table 6 Log monthly reservation and log monthly entry wages

\begin{tabular}{|c|c|c|c|c|c|c|}
\hline & \multicolumn{2}{|l|}{ All } & \multicolumn{2}{|l|}{ Men } & \multicolumn{2}{|l|}{ Women } \\
\hline & $\begin{array}{l}\text { Reservation } \\
\text { wages }\end{array}$ & $\begin{array}{l}\text { Entry } \\
\text { wages }\end{array}$ & $\begin{array}{l}\text { Reservation } \\
\text { wages }\end{array}$ & $\begin{array}{l}\text { Entry } \\
\text { wages }\end{array}$ & $\begin{array}{l}\text { Reservation } \\
\text { wages }\end{array}$ & $\begin{array}{l}\text { Entry } \\
\text { wages }\end{array}$ \\
\hline \multirow[t]{2}{*}{ Age: 26-35 Years (Ref: 18-25) } & 0.0300 & $0.2623 * * *$ & $0.2296 * * *$ & $0.3652 * * *$ & $-0.0917^{*}$ & $0.2868 * * *$ \\
\hline & $(0.0364)$ & $(0.0445)$ & $(0.0524)$ & $(0.0616)$ & $(0.0483)$ & $(0.0595)$ \\
\hline \multirow[t]{2}{*}{ Age: $36-45$ Years } & 0.0309 & $0.2507 * * *$ & $0.2370 * * *$ & $0.4598 * * *$ & -0.0706 & $0.2058 * * *$ \\
\hline & $(0.0377)$ & $(0.0477)$ & $(0.0542)$ & $(0.0641)$ & $(0.0499)$ & $(0.0664)$ \\
\hline \multirow[t]{2}{*}{ Age: $46-55$ Years } & -0.0345 & $0.1267 * *$ & $0.1408 * *$ & $0.3125 * * *$ & $-0.1500^{* * *}$ & 0.0365 \\
\hline & $(0.0387)$ & $(0.0538)$ & $(0.0555)$ & $(0.0778)$ & $(0.0529)$ & $(0.0712)$ \\
\hline \multirow[t]{2}{*}{ Age: 56-65 Years } & -0.0264 & 0.1099 & $0.1516 * *$ & $0.3017 * * *$ & $-0.1787 * *$ & -0.0120 \\
\hline & $(0.0502)$ & $(0.0798)$ & $(0.0649)$ & $(0.0958)$ & $(0.0768)$ & $(0.1302)$ \\
\hline \multirow[t]{2}{*}{ Female } & $-0.3476^{* * *}$ & $-0.5675^{* * *}$ & & & & \\
\hline & $(0.0240)$ & $(0.0299)$ & & & & \\
\hline \multirow[t]{2}{*}{ Children } & $-0.0833 * * *$ & $-0.1506 * * *$ & 0.0201 & $0.1536^{* * *}$ & $-0.1213 * * *$ & $-0.4111 * * *$ \\
\hline & $(0.0265)$ & $(0.0322)$ & $(0.0368)$ & $(0.0439)$ & $(0.0364)$ & $(0.0443)$ \\
\hline \multirow{2}{*}{$\begin{array}{l}\text { School: Intermediate School } \\
\text { (Ref: Secondary School) }\end{array}$} & $-0.0497^{*}$ & $0.1036^{* * *}$ & -0.0464 & 0.0453 & -0.0494 & $0.1470 * * *$ \\
\hline & $(0.0269)$ & $(0.0396)$ & $(0.0367)$ & $(0.0513)$ & $(0.0375)$ & $(0.0556)$ \\
\hline \multirow[t]{2}{*}{ School: Upper School } & $0.1369 * * *$ & $0.0985^{* *}$ & $0.1300 * *$ & -0.0388 & $0.1659 * * *$ & $0.1792 * * *$ \\
\hline & $(0.0397)$ & $(0.0482)$ & $(0.0572)$ & $(0.0663)$ & $(0.0516)$ & $(0.0660)$ \\
\hline \multirow[t]{2}{*}{ Vocational Degree } & 0.0213 & $0.1766^{* * *}$ & $0.0904 * *$ & $0.1299 * * *$ & -0.0106 & $0.1689 * * *$ \\
\hline & $(0.0269)$ & $(0.0365)$ & $(0.0381)$ & $(0.0497)$ & $(0.0349)$ & $(0.0497)$ \\
\hline \multirow[t]{2}{*}{ College Degree } & $0.1709 * * *$ & $0.4437 * * *$ & 0.0509 & $0.3913 * * *$ & $0.2331 * * *$ & $0.4330 * * *$ \\
\hline & $(0.0409)$ & $(0.0493)$ & $(0.0631)$ & $(0.0652)$ & $(0.0524)$ & $(0.0666)$ \\
\hline \multirow[t]{2}{*}{ Health: Normal (Ref: Good) } & -0.0439 & -0.0046 & -0.0494 & -0.0372 & -0.0339 & 0.0040 \\
\hline & $(0.0284)$ & $(0.0342)$ & $(0.0423)$ & $(0.0444)$ & $(0.0361)$ & $(0.0466)$ \\
\hline \multirow[t]{2}{*}{ Health: Bad } & -0.0264 & -0.0742 & -0.0661 & -0.1209 & -0.0272 & -0.0217 \\
\hline & $(0.0308)$ & $(0.0591)$ & $(0.0431)$ & $(0.0890)$ & $(0.0412)$ & $(0.0737)$ \\
\hline \multirow[t]{2}{*}{ Household Income } & 0.0157 & $0.3644 * * *$ & $0.1489 * * *$ & $0.5130 * * *$ & $-0.0727 * * *$ & $0.2565^{* * *}$ \\
\hline & $(0.0212)$ & $(0.0325)$ & $(0.0306)$ & $(0.0480)$ & $(0.0280)$ & $(0.0416)$ \\
\hline \multirow[t]{2}{*}{ German } & $-0.0775^{*}$ & 0.0547 & 0.0426 & $0.1290 *$ & $-0.0982 *$ & 0.0987 \\
\hline & $(0.0442)$ & $(0.0594)$ & $(0.0610)$ & $(0.0707)$ & $(0.0569)$ & $(0.0955)$ \\
\hline \multirow[t]{2}{*}{ Unemployment Rate } & -0.0202 & -0.0270 & 0.0091 & -0.0160 & $-0.0397 *$ & -0.0149 \\
\hline & $(0.0183)$ & $(0.0235)$ & $(0.0297)$ & $(0.0302)$ & $(0.0212)$ & $(0.0347)$ \\
\hline \multirow[t]{2}{*}{ Year 2008} & 0.0189 & -0.0522 & $0.1190 *$ & -0.0567 & -0.0458 & -0.0328 \\
\hline & $(0.0418)$ & $(0.0462)$ & $(0.0684)$ & $(0.0586)$ & $(0.0480)$ & $(0.0664)$ \\
\hline Federal States & Yes & Yes & Yes & Yes & Yes & Yes \\
\hline \multirow[t]{2}{*}{ Constant } & $7.2950 * * *$ & $4.0350 * * *$ & $5.5663 * * *$ & $2.6868 * * *$ & $7.9778 * * *$ & $4.1969 * * *$ \\
\hline & $(0.2549)$ & $(0.3614)$ & $(0.3964)$ & $(0.4713)$ & $(0.3048)$ & $(0.5230)$ \\
\hline$R^{2}$ & 0.1705 & 0.3286 & 0.1717 & 0.3786 & 0.1307 & 0.2567 \\
\hline Adjusted $R^{2}$ & 0.1572 & 0.3179 & 0.1396 & 0.3576 & 0.1076 & 0.2349 \\
\hline$F$-Test & 13.2320 & 31.7960 & 6.2550 & 16.7539 & 7.0934 & 14.4404 \\
\hline Number of observations & 1905 & 1907 & 780 & 888 & 1125 & 1019 \\
\hline Number of individuals & 1522 & 1757 & 617 & 819 & 905 & 938 \\
\hline
\end{tabular}

Notes: OLS, robust standard errors in parentheses

Levels of significance $* * * 1 \%$, * $5 \%$, *10\%, GSOEP 2007/2008 
Table 7 Preferred and actual weekly working hours

\begin{tabular}{|c|c|c|c|c|c|c|c|c|c|}
\hline & \multicolumn{3}{|c|}{ Preferred hours (non-employed) } & \multicolumn{3}{|c|}{ Preferred hours (employed) } & \multicolumn{3}{|c|}{ Actual hours (employed) } \\
\hline & All & Men & Women & All & Men & Women & All & Men & Women \\
\hline $\begin{array}{l}\text { Age: } 26-35 \text { Years } \\
\text { (Ref: } 18-25 \text { ) }\end{array}$ & $\begin{array}{l}-2.8072 * * * \\
(0.7563)\end{array}$ & $\begin{array}{l}0.9346 \\
(1.0208)\end{array}$ & $\begin{array}{l}-4.4669 * * * \\
(1.0147)\end{array}$ & $\begin{array}{l}0.7639 \\
(0.7226)\end{array}$ & $\begin{array}{l}3.4974 * * * \\
(1.0622)\end{array}$ & $\begin{array}{l}-0.0707 \\
(0.9276)\end{array}$ & $\begin{array}{l}3.0895 * * * \\
(0.9337)\end{array}$ & $\begin{array}{l}6.6477 * * * \\
(1.3198)\end{array}$ & $\begin{array}{l}2.0932 * \\
(1.2361)\end{array}$ \\
\hline Age: $36-45$ Years & $\begin{array}{l}-4.0837 * * * \\
(0.7452)\end{array}$ & $\begin{array}{l}0.7573 \\
(0.9384)\end{array}$ & $\begin{array}{l}-5.7636^{* * *} \\
(1.0150)\end{array}$ & $\begin{array}{l}-1.0093 \\
(0.7710)\end{array}$ & $\begin{array}{l}2.4047 * * \\
(1.0952)\end{array}$ & $\begin{array}{l}-2.4865^{* *} \\
(1.0292)\end{array}$ & $\begin{array}{l}1.5538 \\
(0.9664)\end{array}$ & $\begin{array}{l}5.8160 * * * \\
(1.3366)\end{array}$ & $\begin{array}{l}0.2791 \\
(1.3249)\end{array}$ \\
\hline Age: $46-55$ Years & $\begin{array}{l}-5.5939 * * * \\
(0.7765)\end{array}$ & $\begin{array}{l}-1.4789 \\
(1.0309)\end{array}$ & $\begin{array}{l}-8.0066^{* * *} \\
(1.0746)\end{array}$ & $\begin{array}{l}-1.6334 * * \\
(0.7906)\end{array}$ & $\begin{array}{l}2.3495 * * \\
(1.1003)\end{array}$ & $\begin{array}{l}-4.1717 * * * \\
(1.0606)\end{array}$ & $\begin{array}{l}-0.7096 \\
(1.0442)\end{array}$ & $\begin{array}{l}3.7930 * * * \\
(1.4622)\end{array}$ & $\begin{array}{l}-3.1625^{* *} \\
(1.4286)\end{array}$ \\
\hline Age: $56-65$ Years & $\begin{array}{l}-6.8624 * * * \\
(1.0061)\end{array}$ & $\begin{array}{l}-2.9777 * * \\
(1.2791)\end{array}$ & $\begin{array}{l}-10.1251^{* * *} \\
(1.6439)\end{array}$ & $\begin{array}{l}-3.4772^{* * *} \\
(1.1047)\end{array}$ & $\begin{array}{l}0.2108 \\
(1.4860)\end{array}$ & $\begin{array}{l}-5.6007^{* * *} \\
(1.8009)\end{array}$ & $\begin{array}{l}-2.8735^{*} \\
(1.5385)\end{array}$ & $\begin{array}{l}1.7414 \\
(2.0876)\end{array}$ & $\begin{array}{l}-5.7868 * * * \\
(2.1417)\end{array}$ \\
\hline Female & $\begin{array}{l}-7.7125^{* * *} \\
(0.4705)\end{array}$ & & & $\begin{array}{l}-9.0449^{* * *} \\
(0.4618)\end{array}$ & & & $\begin{array}{l}-12.3795^{* * * *} \\
(0.5942)\end{array}$ & & \\
\hline Children & $\begin{array}{l}-3.0764 * * * \\
(0.5423)\end{array}$ & $\begin{array}{l}0.7184 \\
(0.7014)\end{array}$ & $\begin{array}{l}-5.0129 * * * \\
(0.7560)\end{array}$ & $\begin{array}{l}-3.8918^{* * *} \\
(0.4866)\end{array}$ & $\begin{array}{l}0.8612 \\
(0.6651)\end{array}$ & $\begin{array}{l}-7.8543^{* * *} \\
(0.6791)\end{array}$ & $\begin{array}{l}-5.5372 * * * \\
(0.6216)\end{array}$ & $\begin{array}{l}0.6800 \\
(0.8561)\end{array}$ & $\begin{array}{l}-10.7098^{* * *} \\
(0.8468)\end{array}$ \\
\hline $\begin{array}{l}\text { School: Intermediate } \\
\text { School (Ref: } \\
\text { Secondary School) }\end{array}$ & $\begin{array}{l}-0.8089 \\
(0.5532)\end{array}$ & $\begin{array}{l}0.2234 \\
(0.6973)\end{array}$ & $\begin{array}{l}-1.1235 \\
(0.7876)\end{array}$ & $\begin{array}{l}-0.0536 \\
(0.5988)\end{array}$ & $\begin{array}{l}-0.8587 \\
(0.7948)\end{array}$ & $\begin{array}{l}0.5422 \\
(0.8199)\end{array}$ & $\begin{array}{l}1.0936 \\
(0.7758)\end{array}$ & $\begin{array}{l}-0.1804 \\
(1.0938)\end{array}$ & $\begin{array}{l}2.1164 * * \\
(1.0398)\end{array}$ \\
\hline School: Upper School & $\begin{array}{l}-1.0673 \\
(0.7571)\end{array}$ & $\begin{array}{l}-1.1108 \\
(1.0810)\end{array}$ & $\begin{array}{l}-0.4491 \\
(0.9641)\end{array}$ & $\begin{array}{l}-2.0580^{* * *} \\
(0.7811)\end{array}$ & $\begin{array}{l}-2.0417^{*} \\
(1.1327)\end{array}$ & $\begin{array}{l}-2.3708^{* *} \\
(1.0552)\end{array}$ & $\begin{array}{l}-2.0468^{* *} \\
(0.9554)\end{array}$ & $\begin{array}{l}-5.2314^{* * * *} \\
(1.4443)\end{array}$ & $\begin{array}{l}-0.0255 \\
(1.2381)\end{array}$ \\
\hline Vocational Degree & $\begin{array}{l}1.0325^{*} \\
(0.5647)\end{array}$ & $\begin{array}{l}1.4039 * * \\
(0.6859)\end{array}$ & $\begin{array}{l}0.8436 \\
(0.7503)\end{array}$ & $\begin{array}{l}3.0667 * * * \\
(0.5865)\end{array}$ & $\begin{array}{l}1.6156 * \\
(0.8386)\end{array}$ & $\begin{array}{l}3.8076^{* * *} \\
(0.7739)\end{array}$ & $\begin{array}{l}3.1147 * * * \\
(0.7388)\end{array}$ & $\begin{array}{l}1.5797 \\
(1.0462)\end{array}$ & $\begin{array}{l}3.5434 * * * \\
(0.9846)\end{array}$ \\
\hline College Degree & $\begin{array}{l}2.4035^{* * *} \\
(0.8951)\end{array}$ & $\begin{array}{l}2.4639 \\
(1.5971)\end{array}$ & $\begin{array}{l}2.4907 * * \\
(1.0259)\end{array}$ & $\begin{array}{l}4.3629 * * * \\
(0.7471)\end{array}$ & $\begin{array}{l}1.9600 * \\
(1.0657)\end{array}$ & $\begin{array}{l}5.3730 * * * \\
(0.9931)\end{array}$ & $\begin{array}{l}6.3456 * * * \\
(0.9908)\end{array}$ & $\begin{array}{l}5.4331 * * * \\
(1.4282)\end{array}$ & $\begin{array}{l}6.2646^{* * *} \\
(1.3119)\end{array}$ \\
\hline $\begin{array}{l}\text { Health: Normal (Ref: } \\
\text { Good) }\end{array}$ & $\begin{array}{l}-0.2383 \\
(0.5598)\end{array}$ & $\begin{array}{l}-0.1607 \\
(0.7703)\end{array}$ & $\begin{array}{l}-0.2152 \\
(0.7216)\end{array}$ & $\begin{array}{l}0.1881 \\
(0.5312)\end{array}$ & $\begin{array}{l}0.2448 \\
(0.7400)\end{array}$ & $\begin{array}{l}0.0931 \\
(0.7089)\end{array}$ & $\begin{array}{l}0.4025 \\
(0.6688)\end{array}$ & $\begin{array}{l}-0.0546 \\
(0.9479)\end{array}$ & $\begin{array}{l}0.5455 \\
(0.8560)\end{array}$ \\
\hline Health: Bad & $\begin{array}{l}1.0623 \\
(0.6486)\end{array}$ & $\begin{array}{l}0.4617 \\
(0.8335)\end{array}$ & $\begin{array}{l}0.8898 \\
(0.9035)\end{array}$ & $\begin{array}{l}-0.2834 \\
(0.8385)\end{array}$ & $\begin{array}{l}0.2880 \\
(1.2526)\end{array}$ & $\begin{array}{l}0.0761 \\
(1.0371)\end{array}$ & $\begin{array}{l}-0.2775 \\
(1.1995)\end{array}$ & $\begin{array}{l}-1.2535 \\
(1.7495)\end{array}$ & $\begin{array}{l}1.0579 \\
(1.5274)\end{array}$ \\
\hline Household Income & $\begin{array}{l}-1.1407 * * * \\
(0.3980)\end{array}$ & $\begin{array}{l}1.4748^{* * *} \\
(0.5433)\end{array}$ & $\begin{array}{l}-2.8197 * * * \\
(0.5349)\end{array}$ & $\begin{array}{l}-0.0684 \\
(0.4926)\end{array}$ & $\begin{array}{l}1.1116 \\
(0.7368)\end{array}$ & $\begin{array}{l}-0.8210 \\
(0.6190)\end{array}$ & $\begin{array}{l}3.9578^{* * *} \\
(0.6178)\end{array}$ & $\begin{array}{l}4.9854 * * * \\
(0.9234)\end{array}$ & $\begin{array}{l}3.4911 * * * \\
(0.7958)\end{array}$ \\
\hline German & $\begin{array}{l}-0.7784 \\
(1.0001)\end{array}$ & $\begin{array}{l}3.8876^{* * *} \\
(1.3251)\end{array}$ & $\begin{array}{l}-2.3240 * \\
(1.3181)\end{array}$ & $\begin{array}{l}-1.4296 \\
(0.9485)\end{array}$ & $\begin{array}{l}-0.3105 \\
(1.1026)\end{array}$ & $\begin{array}{l}-0.7721 \\
(1.4767)\end{array}$ & $\begin{array}{l}-1.9503 \\
(1.2129)\end{array}$ & $\begin{array}{l}-1.1907 \\
(1.6065)\end{array}$ & $\begin{array}{l}-0.2082 \\
(1.6918)\end{array}$ \\
\hline $\begin{array}{l}\text { Unemployment } \\
\text { Rate }\end{array}$ & $\begin{array}{l}-0.0933 \\
(0.3592)\end{array}$ & $\begin{array}{l}0.0363 \\
(0.5246)\end{array}$ & $\begin{array}{l}-0.1645 \\
(0.4711)\end{array}$ & $\begin{array}{l}-0.1555 \\
(0.3341)\end{array}$ & $\begin{array}{l}0.0150 \\
(0.4705)\end{array}$ & $\begin{array}{l}-0.0062 \\
(0.4678)\end{array}$ & $\begin{array}{l}-0.5432 \\
(0.4646)\end{array}$ & $\begin{array}{l}0.1214 \\
(0.6687)\end{array}$ & $\begin{array}{l}-0.7837 \\
(0.6257)\end{array}$ \\
\hline Year 2008 & $\begin{array}{l}0.3331 \\
(0.8048)\end{array}$ & $\begin{array}{l}0.4747 \\
(1.1332)\end{array}$ & $\begin{array}{l}0.2515 \\
(1.0470)\end{array}$ & $\begin{array}{l}-1.1242 \\
(0.7259)\end{array}$ & $\begin{array}{l}-1.3710 \\
(1.0443)\end{array}$ & $\begin{array}{l}-0.3478 \\
(0.9710)\end{array}$ & $\begin{array}{l}-0.9949 \\
(0.9554)\end{array}$ & $\begin{array}{l}-1.1127 \\
(1.3734)\end{array}$ & $\begin{array}{l}-0.5096 \\
(1.2492)\end{array}$ \\
\hline Federal States & Yes & Yes & Yes & Yes & Yes & Yes & Yes & Yes & Yes \\
\hline Constant & $\begin{array}{l}52.3702^{* * *} \\
(5.0219)\end{array}$ & $\begin{array}{l}22.3605^{* * *} \\
(6.8793)\end{array}$ & $\begin{array}{l}61.6668 * * * \\
(6.5655)\end{array}$ & $\begin{array}{l}41.1011^{* * *} \\
(5.4649)\end{array}$ & $\begin{array}{l}26.3513^{* * *} \\
(7.7169)\end{array}$ & $\begin{array}{l}38.3001^{* * *} \\
(7.1140)\end{array}$ & $\begin{array}{l}15.3961^{* * *} \\
(6.9622)\end{array}$ & $\begin{array}{l}-0.8641 \\
(10.1976)\end{array}$ & $\begin{array}{l}8.6833 \\
(8.9957)\end{array}$ \\
\hline$R^{2}$ & 0.2604 & 0.0823 & 0.2601 & 0.2717 & 0.0721 & 0.2673 & 0.2818 & 0.1374 & 0.2472 \\
\hline Adjusted $R^{2}$ & 0.2485 & 0.0468 & 0.2405 & 0.2600 & 0.0407 & 0.2458 & 0.2703 & 0.1082 & 0.2252 \\
\hline$F$-Test & 23.9937 & 1.9116 & 19.2132 & 25.0348 & 2.0623 & 15.7000 & 28.3786 & 4.5401 & 13.3876 \\
\hline $\begin{array}{l}\text { Number of } \\
\text { observations }\end{array}$ & 1905 & 780 & 1125 & 1907 & 888 & 1019 & 1907 & 888 & 1019 \\
\hline Number of individuals & 1520 & 617 & 905 & 1757 & 819 & 938 & 1757 & 819 & 938 \\
\hline
\end{tabular}

Notes: OLS, robust standard errors in parentheses

Levels of significance $* * * 1 \%, * * 5 \%, * 10 \%$, GSOEP 2007/2008 
outcome of leisure preferences. Therefore, we also analyze the effect of age on satisfaction with leisure and job satisfaction. Happiness research in economics has received increasing attention in recent years. Frey and Stutzer (2002) found that satisfaction is at least somewhat related to the utility concept. We use the information about satisfaction in the relevant domains of leisure and work in order to see if systematic age differences exist. From a ceteris paribus perspective, such systematic differences are likely to reflect preference changes with age, because we control for household income as proxy for endowment with wealth. In order to reduce further individual heterogeneity in the estimates, we include a control variable for general life satisfaction. The main result in Table 8 is that older individuals are on average happier with their leisure but not with their jobs and that this age effect is stronger for women than for men. ${ }^{8}$ This finding can be interpreted as with age increasing preferences for leisure relative to work (e.g. Gordon and Blinder 1980), which may explain the higher reservation wages and lower labor supply that result in the lower employment rates of older workers, especially older women.

The results of our reduced-form regressions are largely descriptive, although we control for important differences in socio-economic characteristics and age and gender should be exogenous variables. As robustness checks for our results from the pooled cross-sections 2007 and 2008 we use panel estimation techniques (random and fixed effect linear models) for the years 1997 to 2008 in order to reduce problems stemming from unobserved heterogeneity. ${ }^{9}$ The results from the panel estimates generally support our main results from the pooled cross-sections for preferred weekly working hours, actual weekly working hours, and satisfaction with leisure and job. For our main outcome variables of interest, namely reservation and entry wages, we cannot use panel estimation techniques for the following reasons. First, information about hourly reservation wages is not included in the GSOEP prior to the year 2007. Second, reservation wages can only be observed for non-employed job searchers so that longitudinal information would only be available for the long-term unemployed and individuals who experience repeated unemployment. Third, entry wages are only observed once at the start of an employment relationship.

\footnotetext{
${ }^{8} \mathrm{We}$ find a positive effect of children on male satisfaction with jobs, but a negative effect on female satisfaction with leisure. These opposite effects for mothers and fathers may reflect the childcare stress of a traditional family model. See for instance the surveys on parental satisfaction by Hansen (2012), and Margolis and Myrskylä (2011).

${ }^{9}$ The complete results of the panel estimates can be found in our longer working paper (Humpert and Pfeifer 2011).
}

\section{Conclusion}

In times of demographic change, it is a challenge for policy and human resource management to activate the resources of females and older people in the labor market to maintain a sufficiently large labor supply and to reduce financial problems in retirement schemes. Such an activation strategy is motivated by the empirical observation that employment rates decrease with age among the elderly and are lower for women than for men. Much political concern focuses on the employer side and leads to appeals to recruit more women and older workers. Without neglecting the fact that discrimination is an important issue, our paper has taken the opposite view and has found empirical support for labor supply-side explanations of differences in employment rates. From a theoretical perspective (neoclassical labor supply model, job search models) individuals voluntarily choose non-employment over employment if their reservation wages are larger than the wages offered by firms. We have indeed found empirical evidence that hourly reservation wages increase with age for men and for women. Hourly entry wages as proxy for offered wages increase with age only for men, however, and not for women, which may partly explain the increasing gender gap in employment rates. These findings differ from previous research. Brown et al. (2010) use British household data (BHPS), but only for men, to show increasing hourly reservation wages until the ages of 45 to 54 . In the highest age group of 55 and older, reservation wages decline. This is in contrast with our findings, where hourly reservation wages of males older than 55 are still increasing. These authors have an advantage in terms of their data, however. Whereas in the BHPS reservation wages per hour are collected for years, we have new information in the GSOEP data beginning in 2007. Our result of $\mathrm{u}$-shaped patterns of monthly reservation wages is in line with other researchers using the monthly GSOEP data. In these papers, there are higher monthly reservation wages for men than for women (Christensen 2005; Prasad 2001, 2004; Pannenberg 2010). Christensen (2005) uses squared age functions and reports u-shaped age profiles separately for West German men and women. Prasad (2001, 2004) shows an inverse u-shaped age profile, but has limited the age span to 55, and reports mostly non-significant coefficients.

As a methodological contribution, we show that the specification of the reservation wage as an hourly variable instead of a monthly variable yields more plausible results, because age and gender have simultaneous effects on hourly reservation wages and preferred working hours. Older workers and women prefer to work fewer hours and actually do so. In combination with the result that satisfaction with leisure increases relative to job satisfaction, our findings support the statement of Gordon and Blinder (1980, p. 278) 


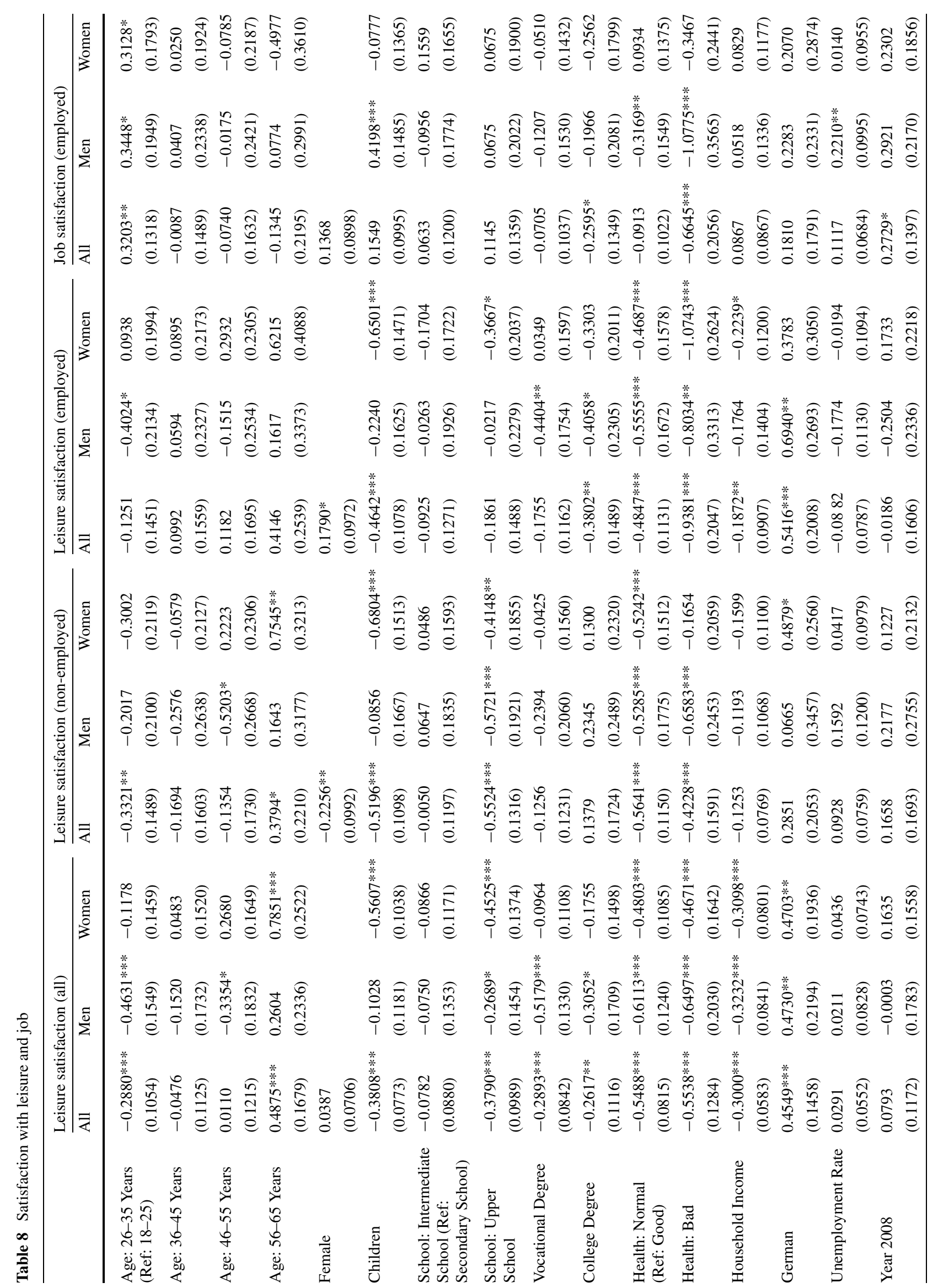


that " $(\ldots)$ as people age, their preferences may shift in favor of leisure and against work." Consequently, the lower employment rates of women and older people can be partly attributed to the labor supply side and not necessarily to the labor demand side. One active labor market policy could be an effort to increase, or at least maintain, the productivity of women and older workers so that they obtain higher wage offers from firms. This could be accomplished by special training programs inside and outside firms, which are targeted at older people, especially women. Zwick (2012), for example, shows that training for older workers is less effective, because of the methods used. Younger and older workers have different ways of teaching and learning. Second, policy could subsidize employment, especially reintegration in the labor market (e.g. direct transfers, tax reductions), which would also increase offered wages and the employment probability. Such policy measures are costly however and might conflict with the goal of sustainable public debt. Thus, econometric evaluation and simulation studies on the effects of such labor market policies are needed in order to facilitate conclusive policy recommendations.

Furthermore, we have found gender-specific differences in the family context. The presence of children in the household increases the reservation wages of women and negatively affects their labor supply, whereas neither reservation wages nor working hours of men are significantly affected. This is in fact contrary to the results of Prasad. Using monthly reservation wages, Prasad (2001) shows that having children lowers reservation wages in general, and Prasad (2004) finds higher reservation wages for fathers but not for mothers.

These findings point to the dominance of the traditional family model in Germany wherein mothers bear the main responsibility for raising children, voluntarily or involuntarily. In order to activate more mothers for the labor market, firms as well as policy should continue the expansion of more flexible working time schedules and day care for children at the workplace and in the close neighborhood. Especially in the case of Germany, additional full-time school programs might help parents to reduce time restrictions.

\section{Executive summary}

Individuals voluntarily choose non-employment over employment if their reservation wages are larger than the wages offered by firms. We use this theoretical considerations as an explanation for lower employment rates of older workers and women in Germany. The GSOEP data (German SocioEconomic Panel), a large-scale household panel, is used to analyze average age and gender differences in reservation wages and entry wages as proxy for offered wages. Furthermore we analyze differences in preferred and actual working 
hours, and leisure and job satisfaction. As a methodological contribution, we show that the specification of the reservation wage as an hourly variable instead of a monthly variable yields more plausible results, because age and gender have simultaneous effects on hourly reservation wages and preferred working hours. It is a limitation of our study that we only use information for the years of 2007 and 2008.

In our empirical analysis, we find that older workers have larger hourly reservation wages but lower monthly reservation wages owing to their preference for working fewer hours. The estimated age effects are larger for women than men. Our results of increasing hourly reservation wages with age are contrary to other studies, which report only declining monthly reservation wages. We further find that the presence of children in the household increases reservation wages and reduces the supplied working hours of women, whereas no significant effects are detected for men. Hourly entry wages increase with age only for men and not for women, which may partly explain an increasing gender gap in employment rates. Older workers and women prefer to work fewer hours and actually do so. Satisfaction with leisure increases with age while job satisfaction declines.

\section{Kurzfassung}

Personen entscheiden sich für freiwillige Nichtbeschäftigung, sofern ihr individueller Reservationslohn größer ist als ein angebotener Marktlohn. Wir nutzen diese theoretische Überlegung, um damit sinkende Beschäftigungsquoten älterer und weiblicher Personen zu erklären. Mittels der SOEP Daten (Sozio-oekonomisches Panel), einem großen Haushaltspanel, werden durchschnittliche alters- und geschlechtsspezifische Unterschiede von Reservations- und Eintrittslöhnen bzw. Lohnangeboten untersucht. Weiterhin werden Unterschiede in Bezug auf gewünschte und tatsächliche Arbeitsstunden sowie die Zufriedenheit mit Arbeit und Freizeit betrachtet. Als methodischen Beitrag zeigen wir, dass auf Stundenbasis gemessene Reservationslöhne zu glaubhafteren Ergebnissen führen, als auf Monatsbasis gemessene. Dies liegt daran, dass Alter und Geschlecht simultan auf den Stundenreservationslohn und die gewünschten Arbeitsstunden wirken. Eine Beschränkung der Studie ist, dass wir nur Informationen für die Jahre 2007 und 2008 zur Verfügung haben.

In unserer empirischen Analyse finden wir, dass älterer Personen auf Grund ihrer Präferenz für weniger Arbeitsstunden größere Stundenreservationslöhne, aber geringere Monatsreservationslöhne haben. Die Alterseffekte sind hierbei für Frauen deutlicher ausgeprägt. Das Ergebnisse von mit dem Alter ansteigenden Stundenreservationslöhnen widerspricht anderen Studien, stimmen aber für sinkende Monatsreservationslöhne überein. Des Weiteren zeigen wir, dass bei
Anwesenheit von Kindern im Haushalt der Reservationslohn von Frauen steigt und ihre angebotenen Arbeitsstunden sinken. Für Männer gibt es keinen signifikanten Effekt. Eintrittslöhne auf Stundenbasis steigen mit dem Alter nur bei den Männern, nicht aber bei den Frauen. Dies kann eine wachsende geschlechtsspezifische Lücke in den Beschäftigungsquoten erklären. Ältere Personen und Frauen wünschen weniger Arbeitsstunden und arbeiten tatsächlich auch weniger. Die Zufriedenheit mit der Freizeit steigt mit dem Alter, während die Zufriedenheit mit der Arbeit abnimmt.

Acknowledgements This work was financially supported by the VolkswagenStiftung. We thank participants of the SOEP User Conference 2012, EALE 2011 in Pafos, the Colloquium in Personnel Economics 2011 in Zurich and colleagues in research seminars at Leuphana University Lüneburg and University Hamburg for their comments. We thank the editor Bernd Fitzenberger and two anonymous referees for their comments.

\section{References}

Addison, J.T., Centeno, M., Portugal, P.: Do reservation wages really decline? Some international evidence on the determinants of reservation wages. J. Labor Res. 30(1), 1-8 (2009)

Beblo, M., Bender, S., Wolf, E.: Establishment-level wage effect of entering motherhood. Oxf. Econ. Pap. 61(Suppl. 1), i11-i34 (2009)

Black, D.A.: Discrimination in an equilibrium search model. J. Labor Econ. 13(2), 309-334 (1995)

Bloemen, H.G., Stancanelli, E.G.F.: Individual wealth, reservation wages and the transition into employment. J. Labor Econ. 19(2), 400-439 (2001)

Borjas, G.J.: Labor Economics, 5th edn. McGraw-Hill/Irwin, Boston (2009)

Brown, S., Roberts, J., Taylor, K.: Reservation wages, labour market participation and health. J. R. Stat. Soc. A 173(3), 501-529 (2010)

Brown, S., Roberts, J., Taylor, K.: The gender reservation wage gap: evidence from British panel data. Econ. Lett. 113(1), 88-91 (2011)

Browning, M.: Children and household economic behavior. J. Econ. Lit. 30(3), 1434-1475 (1992)

Cahuc, P., Zylberberg, A.: Labor Economics. MIT Press, Cambridge (2004)

Cappellari, L., Tatsiramos, K.: Friends' network and job finding rates. IZA discussion paper, Number 5240 (2010)

Chan, S., Stevens, A.H.: Job loss and employment patterns of older workers. J. Labor Econ. 19(2), 484-521 (2001)

Chang, F.-R.: Uncertain lifetimes, retirement and economic welfare. Economica 58(230), 215-232 (1991)

Christensen, B.: Die Lohnansprüche deutscher Arbeitsloser: Determinanten und Auswirkungen von Reservationslöhnen. Kieler Studien, vol. 333. Springer, Berlin (2005)

Erjnaes, M., Kunze, A.: Work and wage dynamics around childbirth. IZA discussion paper, Number 6066 (2011)

Feldstein, M., Poterba, J.: Unemployment insurance and reservation wages. J. Public Econ. 23(1-2), 141-167 (1984)

Fitzenberger, B., Wilke, R.A.: Unemployment durations in west Germany before and after the reform of the unemployment compensation system during the 1980s. Ger. Econ. Rev. 11(3), 336-366 (2010)

Franz, W.: The reservation wage of unemployed persons in the Federal Republic of Germany: theory and empirical tests. Z. Wirtsch.Sozialwiss. 102(1), 29-51 (1982) 
Frey, B.S., Stutzer, A.: What can economists learn from happiness research? J. Econ. Lit. 40(2), 402-435 (2002)

Gordon, R.H., Blinder, A.S.: Market wages, reservation wages, and retirement decisions. J. Public Econ. 14(2), 277-308 (1980)

Gorter, D., Gorter, C.: The relation between unemployment benefits, the reservation wage and search duration. Oxf. Bull. Econ. Stat. 55(2), 199-214 (1993)

Hansen, T.: Parenthood and happiness: a review of folk theories versus empirical evidence. Social Indicators Research 108(1), 29-64 (2012)

Heckman, J.: Life cycle consumption and labor supply: an explanation of the relationship between income and consumption over the life cycle. Am. Econ. Rev. 64(1), 188-194 (1974)

Humpert, S., Pfeifer, C.: Explaining age and gender differences in employment rates: a labor supply side perspective. University of Lüneburg Working Paper Series in Economics, No. 214 (2011)

Hunt, J.: The effect of unemployment compensation on unemployment duration in Germany. J. Labor Econ. 13(1), 88-120 (1995)

Hutchens, R.M.: Do job opportunities decline with age? Ind. Labor Relat. Rev. 42(1), 89-99 (1988)

Jones, S.R.G.: Reservation wages and the cost of unemployment. Economica 56(222), 225-246 (1989)

Kiefer, N.M., Neumann, G.R.: An empirical job-search model with a test of the constant reservation-wage hypothesis. J. Polit. Econ. 87(1), 89-107 (1979)

Krueger, A.B., Mueller, A.: Job search and job finding in a period of mass unemployment: evidence from high-frequency longitudinal data. Brookings Pap. Econ. Act. 42(1), 1-81 (2011)

Kunze, A., Troske, K.R.: Comparative advantage or discrimination? Studying male-female wage differentials using displaced workers. IZA discussion paper, Number 3052 (2007)

Kunze, A., Troske, K.R.: Life-cycle patterns in male/female differences in job search. Labour Econ. 19(2), 176-185 (2012)

Lazear, E.P.: Why is there mandatory retirement? J. Polit. Econ. 87(6), 1261-1284 (1979)

Lazear, E.P.: Retirement from the labor force. In: Ashenfelter, O.C., Card, D. (eds.) Handbook of Labor Economics, vol. 1, pp. 305355. Elsevier, Amsterdam (1986)

Ljungqvist, L., Sargent, T.J.: Two questions about European unemployment. Econometrica 76(1), 1-29 (2008)

Maani, S.A., Studenmund, A.H.: The critical wage, unemployment duration and wage expectations: the case of Chile. Ind. Labor Relat. Rev. 39(2), 264-276 (1986)

Margolis, R., Myrskylä, M.: A global perspective on happiness and fertility. Popul. Dev. Rev. 37(1), 29-56 (2011)

McCall, J.J.: Economics of information and job search. Q. J. Econ. 84(1), 113-126 (1970)

Miller, A.R.: The effect of motherhood timing on career path. J. Popul. Econ. 24(3), 1071-1100 (2011)

Mortensen, D.T.: Job search, the duration of unemployment and the Phillips Curve. Am. Econ. Rev. 60(5), 847-862 (1970)

Mortensen, D.T., Pissarides, C.A.: New developments in models of search in the labor market. In: Ashenfelter, O.C., Card, D. (eds.) Handbook of Labor Economics 3b, pp. 2567-2627. Elsevier, Amsterdam (1999)
Pannenberg, M.: Risk attitudes and reservation wages of unemployed workers: evidence from panel data. Econ. Lett. 106(3), 223-226 (2010)

Prasad, E.S.: The dynamics of reservation wages: preliminary evidence from the GSOEP. Vierteljahrsh. Wirtschaftsforsch. 70(1), 44-50 (2001)

Prasad, E.S.: What determines the reservation wage of unemployed workers? New evidence from German micro data. In: Fagan, G., Mongelli, F.P., Morgan, J. (eds.) Institutions and Wage Formation in the New Europe, pp. 32-52. Edward Elgar, Cheltenham (2004)

Rogerson, R., Shimer, R., Wright, R.: Search-theoretic models of the labor market: a survey. J. Econ. Lit. 43(4), 959-988 (2005)

Schleife, K.: Computer use and employment status of older workers: an analysis based on individual data. Labour: Rev. Labour Econ. Ind. Relat. 20(2), 325-348 (2006)

Schmidt, C.M., Winkelmann, R.: Reservation wages, wage offer distribution and accepted wages. In: Bunzel, H., Jensen, P., WestergardNielsen, N. (eds.) Panel Data and Labour Market Dynamics, pp. 149-170. North-Holland, Amsterdam (1993)

Schönberg, U., Ludsteck, J.: Maternity leave legislation, female labor supply, and the family wage gap. IZA discussion paper, Number 2699 (2007)

Sestito, P., Viviani, E.: Reservation wages: explaining some puzzling regional patterns. Labour: Review of Labour Economics and Industrial Relations 25(1), 63-88 (2011)

Shimer, R., Werning, I.: Reservation wages and unemployment insurance. Q. J. Econ. 122(3), 1145-1185 (2007)

Sommerfeld, K.: Older babies-more active mothers? How maternal labor supply changes the child grows. Schmollers Jahrb. Wirtsch.Soz.wiss. 129(2), 227-240 (2009)

Steiner, V.: Unemployment persistence in the West German labour market: negative duration dependence or sorting? Oxf. Bull. Econ. Stat. 63(1), 91-113 (2001)

Wagner, G.G., Frick, J.R., Schupp, J.: The German Socio Economic Panel Study (SOEP): scope, evolution and enhancements. Schmollers Jahrb. Wirtsch.- Soz.wiss. 127(1), 139-169 (2007)

Zwick, T.: Training on older employees: what is effective? Mimeo (2012)

Stephan Humpert studied economics and social sciences at the University of Rostock. He received a bachelor in social sciences in 2007 and a master in economics in 2009. Since January 2010 he is a research assistant and a doctoral student at Leuphana University Lüneburg. His research focus is on empirical labour and population economics.

Christian Pfeifer studied economics and management at Leibniz University Hannover, Germany, and Maastricht University, Netherlands. He received his Diploma (Master equivalent) in 2003 and doctoral degree in 2007 from Leibniz University Hannover. From 2007 to 2009 he was a Post-Doc at Leibniz University Hannover and University of California Berkeley. Since September 2009 he is Professor (W1) of Economics at Leuphana University Lüneburg. His research focus is on empirical labour and personnel economics. 